\title{
The Effect of Environmental Factor, Population and Age of Duck on Egg Production
}

\author{
Ismoyowati , Imam Suswoyo, Rosidi, Sigit Mugiyono and Nu'man Hidayat \\ Faculty of Animal Science, Jenderal Soedirman University, Purwokerto, Indonesia \\ ${ }^{*}$ Corresponding author email: ismoyowati@unsoed.ac.id
}

\begin{abstract}
Duck is one of the commodities that contribute to the national livestock production and Central Java is home to the fourth biggest duck population after West Java, South Sulawesi and East Java. The 2019 egg production in Central Java was 36.174 tons or $11.3 \%$ of the total egg production nationwide. Accordingly, it is important to investigate the effect of environmental factor, total number and age of ducks on egg production in Central Java. Specifically, this study aimed to observe the effect of region on egg production and feed conversion ratio (FCR) and the total livestock (chicken), age (month), stocking density (ducks $/ \mathrm{m}^{2}$ ), internal housing temperature $\left({ }^{\circ} \mathrm{C}\right)$, and humidity (\%) on Hen day production/HDP. A survey engaging purposive random sampling was conducted on the population of duck farming in Central Java especially Tegal, Pemalang and Brebes districts. The data were subjected to General Linear Model (GLM) and a regression-correlation analysis using an SPSS program. The result showed that region significantly affected hen day production (HDP) but did not affect FCR. Housing temperature affected HDP by $14.9 \%$ and the higher the temperature, the lower the HDP. Duck age affected HDP by $11.7 \%$, and the older the ducks the lower the egg production. Duck population, stocking density and humidity did not significantly affect egg production. Conclusively, duck egg production (HDP) is significantly affected by temperature inside the housing and the duck age.
\end{abstract}

Keywords: duck farming, hen day production, FCR, environment factor

\begin{abstract}
Abstrak. Itik merupakan salah satu komoditas yang memberikan kontribusi pada produksi hasil ternak nasional dan provinsi Jawa Tengah merupakan wilayah dengan populasi itik terbesar keempat setelah Jawa Barat, Sulawesi selatan dan Jawa Timur. Produksi telur itik di Jawa Tengah pada tahun 2019 sebesar 36.174 ton atau $11,3 \%$ dari total produksi telur nasional, oleh karena itu penting dilakukan penelitian yang mengkaji pengaruh faktor lingkungan, jumlah dan umur itik terhadap produksi telur di wilayah Jawa Tengah. Penelitian ini bertujuan untuk mengetahui pengaruh wilayah terhadap produksi telur dan rasio konversi pakan (FCR) serta untuk mengetahui pengaruh jumlah ternak (ekor), umur ternak (bulan), kepadatan kandang (ekor $/ \mathrm{m}^{2}$ ), suhu $\left({ }^{\circ} \mathrm{C}\right)$ dan kelembaban $(\%)$ dalam kandang terhadap produksi telur harian (Hen day production). Penelitian dilakukan menggunakan metode survey dengan pengambilan sampel secara purposive random sampling. Sasaran penelitian adalah populasi pada peternakan itik di Jawa Tengah, wilayah kabupaten Tegal, Pemalang dan Brebes. Analisis data menggunakan General Linier Model (GML) dan analisis regresi-korelasi. Analisis data dilakukan dengan program SPSS. Hasil penelitian menunjukkan bahwa wilayah berpengaruh nyata terhadap produksi telur harian, sedangkan wilayah tidak berpengaruh terhadap FCR. Hasil penelitian menunjukkan bahwa faktor lingkungan suhu berpngaruh terhadap HDP sebesar 14,9\%, semakin tinggi suhu kadang semakin rendah HDP nya. Umur itik berpengaruh terhadap HDP sebesar $11,7 \%$, semakin tua umur itik produksi telur semakin menurun. Jumlah itik, kepadatan dan kelembaban kandang berpengaruh tidak nyata terhadap produksi telur. Kesimpulan penelitian adalah Produksi telur itik (HDP) sangat dipengaruhi oleh suhu di dalam kandang dan umur itik.
\end{abstract}

Kata Kunci: peternakan itik, produksi telur, FCR, faktor lingkungan

\section{Introduction}

Indonesia is a country famous for its high biodiversity, including ducks. Ducks have been known for centuries as a commodity among Indonesian community, farmed as an income source which provides job opportunities as well as a source of protein for its highly nutritious eggs and meat. The duck population in
Indonesia is the third biggest worldwide only after China and Vietnam (Ismoyowati and Sumarmono, 2019). The 2019 duck population in Indonesia increased by 8.099\% from 2018 (Directorate General of Livestock and Animal Health Services, 2019).

Native duck in Indonesia is the Indian runner species notable for its eggs and various 
productivity. Different types of ducks in Indonesia are named according to the place of development, such as Tegal duck, Magelang duck, Mojosari duck and Alabio duck. Duck population is concentrated in Java island and other western part (Ismoyowati and Purwantini, 2013). Central Java is one of the biggest producers of egg after West Java, South Sulawesi, and East Java. Central Java recorded $5,340,932$ ducks or $10.28 \%$ of the total population, and the egg production reach 36.174 ton/year (Directorate General of Livestock and Animal Health Services, 2019).

Ducks in Central Java are dominated by several types, including Tegal duck and Magelang duck. The main purpose of Tegal duck farming in Central Java is to produce eggs, from small to large scale. The production and quality of duck eggs are affected by the farmers' management system (Directorate General of Livestock and Animal Health Services, 2019), as well as genetic factors. The other contributing factors to egg production include genetic selection and different strains of the livestock (Subiharta et al., 2013).

Egg production is managed genetically by default, but it could be modified by environmental factors such as livestock population (bird), livestock age (month), feed intake ( $\mathrm{g} / \mathrm{bird} /$ day), stocking density (bird $\left./ \mathrm{m}^{2}\right)$, in-housing temperature $\left({ }^{\circ} \mathrm{C}\right)$, humidity $(\%)$, vaccination and nutrition (Ratriyanto et al., 2019). The housing is one main factor to duck egg production. A housing with high temperature, humidity, stocking density and obstructed ventilation may cause a high ammonia level inside the cage which prevents duck from optimum production (Talukder et al., 2010).

Ambient temperature affects the body condition of livestock. A comfortable duck would have an optimum and good production. It is closely related to the temperature and climate of the farming place. Meanwhile, the temperature of Central Java ranges from $20.7^{\circ} \mathrm{C}$ to $37^{\circ} \mathrm{C}$. Therefore, it is important to evaluate the effect of environmental factors and the characteristics of duck farming in Central Java on egg production. The objective of the present study is to investigate the effect of environmental factors, which include stocking density $\left(\mathrm{bird} / \mathrm{m}^{2}\right)$, temperature $\left({ }^{\circ} \mathrm{C}\right)$ and humidity (\%) inside the house, as well as the duck population and age on duck egg production (Hen day production).

\section{MATERIALS AND METHODS}

This study conducted a survey with a purposive random sampling to duck farming in Central Java. The coverage regions for samples included Tegal, Pemalang and Brebes - three most populated cities/districts in Central Java.The primary data source was obtained from a direct observation in duck farming as well as questionnaire and interview with the farmers.

This study targeted several duck farming/breeder farmer groups in these regions. In Tegal were duck farming groups 'Kemiri Barat' (26 farmers) and 'Satelit Sejahtera' (39 farmers). In Pemalang district were 'Bulusari' (23 farmers) and Klareyan (15 farmers), while in Brebes district were 'Maju Jaya' (22 farmers) and 'Sumber Pangan' (26 farmers). From each district, 40 duck farms were selected as the samples using a purposive random sampling with two criteria: minimum 100 bird population and 8-12 months production period, so the total samples were 120 duck farms. The observation was conducted for two months.

The data were subjected to analysis of variance based on General Linear Model (GML) and a regression-correlation analysis. The measured variables were egg production (hen day production), FCR, duck age, duck population, stocking density, housing humidity, and housing temperature. Data analysis was run with SPSS program. 


\section{Results and Discussion}

\section{The effect of region on Egg production and Feed Conversion Rate}

Duck is a commodity of protein source from its meat or eggs. Ducks are widespread in Indonesia regions, including Central Java. Regions with the highest duck egg production in Central Java may include Tegal, Pemalang and Brebes. The farming region could affect egg production and feed conversion rate (FCR) of the livestock (Table 1). Table 1 shows the effect of region on duck egg production and FCR in Central Java.

The analysis of variance showed that region significantly $(\mathrm{P}<0.05)$ affected hen day production (Table 1). Pemalang had the highest HDP as opposed to Brebes and Tegal. The higher egg production could be attributed to a proper environmental condition. Jones and Dawkines (2010) stated that heat would trigger the animals to drink more, which may prevent an optimum absorption of nutrition intake; consequently, the egg production decreases. The higher cage temperature in Pemalang region than Brebes and Tegal may have caused this issue. Widiyaningrum et al. (2016) stated that duck productivity in each region is different because of some factors, such as climate, temperature, humidity, management system, feed content and genetic factor of the livestock. Also, Ismoyowati et al. (2018) mentioned that cage temperature above $30^{\circ} \mathrm{C}$ may trigger heat stress, which directly impacts the egg production. Daghir (2009) stated that offering feed with low protein and amino acid (particularly methionine and lysine) during heat stress would result in a better productivity than that with high protein diet.

Egg production is a process of synthesizing protein and other nutrition, which accumulate as an egg in the livestock body. Therefore, feed protein is significant to determine the sufficient protein intake. The ambient temperature and energy content in the feed would affect the feed intake (Ismoyowati et al., 2018). Different egg production in each region is potentially due to low absorption of nutrition feed because the body temperature increases. Lin et al. (2006) stated that half of protein synthesis is used to eliminate body heat; as a result, duck production declines. High-protein feed offered to ducks in a region with high-heat temperature could reduce protein synthesis and increase nitrogen level in the manure. A study by Baruwa et al. (2018) reported that an increasing egg productivity of native ducks in Nigeria was attributed to farming management and socioeconomic factors of the farmers. The egg production of native ducks in Indonesia is relatively similar to Khaki Campbell ducks (71.15\%) and native India ducks (57.81\%) (Giri et al., 2014).

The result (Table 1 ) shows that the duck farming region did not significantly $(P>0.05)$ affect feed conversion rate (FCR) ( $P>0.05)$. FCR is similar across the regions of study. Zhang et al. (2020) stated that FCR value in duck egg farmers was 2.7 to 3.3. The present study reported a non-significant difference in FCR across regions because the three regions have a relatively similar elevation.

Table 1. The mean of duck egg production and feed conversion ratio in Tegal, Pemalang and Brebe

\begin{tabular}{lccc}
\hline \multirow{2}{*}{ Variables } & \multicolumn{3}{c}{ Area } \\
\cline { 2 - 4 } & Tegal & Pemalang & Brebes \\
\hline Egg production (\%) & $62.12 \pm 7.79^{\mathrm{b}}$ & $72.02 \pm 6.53^{\mathrm{a}}$ & $64.84 \pm 14.16^{\mathrm{b}}$ \\
Feed conversion ratio & $3.52 \pm 0.54$ & $3.61 \pm 0.71$ & $3.65 \pm 0.64$ \\
\hline
\end{tabular}

Note: Values bearing different superscript within rows show significant differences $(P<0.05)$ 
Qurniawan et al. (2016) reported that FCR is affected by the elevation, and the higher the region, the bigger the FCR. Meanwhile, Basso et al. (2012) indicated that FCR of laying ducks aged 40-48 weeks was 4,1. Widianto et al. (2015) stated that the FCR is one of the parameters feed quality offered to the livestock to fulfill nutrition demand.

FCR of ducks in Central Java in this study is relatively high (3.52 to 3.65 ). One study by Ketaren and Prasetyo $\left(2002^{\mathrm{a}, \mathrm{b}}\right)$ reported that FCR of layer ducks in Indonesia is relatively high, around 3.2 to 5 . It indicates that the feed quality offered by several farmers in Central Java is still low. Also, Rohimah et al. (2017) showed that the lower the FCR, the better the feed absorption in the livestock body. Thiele and Alletru (2017) stated that FCR can be used as a growth parameter. Daily feed intake is employed to increase body weight gain and egg production. High FCR in layer ducks may be due to several factors, including genetic factor, feed content and leftover feed.

The correlation between duck population, duck egg, as well as environmental factors and Hen Day Production

Duck farming productivity is affected by the duck population, environmental factor and genetic factor. Some environmental factors investigated in the present study included housing temperature, housing density and housing humidity, while the duck condition observed was the population and age. The result of regression-correlation showed that duck population, stocking density and housing humidity did not significantly affect egg production (Figure 1). The duck population in a farm does not respond significantly because egg production is calculated based on the total number of hens (production period) in each farm. Hen Day Production (HDP) is formulated to tell the total eggs produced by a group of livestock at a particular age (Hastuti et al., 2018). The present study demonstrated that the highest HDP value is in Pemalang region (72.02\%), followed by Brebes (64.84\%) and Tegal (62.11\%). However, Manurung et al. (2019) reported HDP of Tegal ducks under $50 \%$. It indicates that the present study used ducks at productive age for laying eggs, hence the HDP above $50 \%$. Additionally, previous findings by Samsudin et al. (2016) reported HDP around 60$78 \%$.

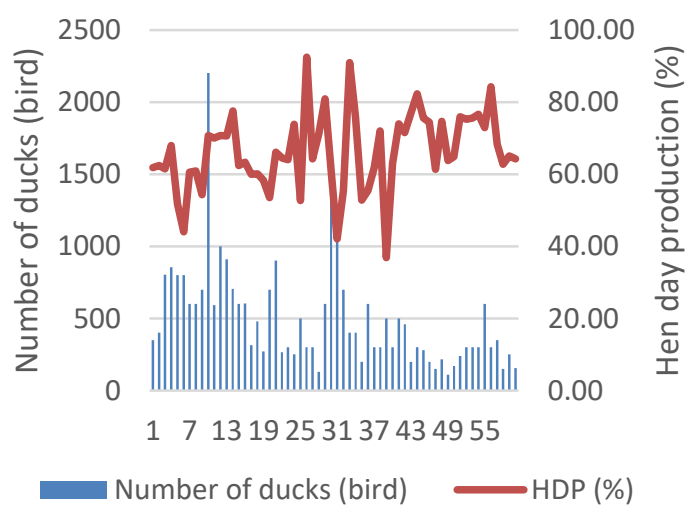

Figure 1. The graph of the number of ducks and hen day production

Housing density is a contributing factor to productivity. An overly populated housing would trigger stress in the livestock and result in economic loss to farmers, but a severely low populated housing would affect the efficiency of housing utilization. The result of regressioncorrelation analysis shows that stocking density did not significantly affect egg production (Figure 2). The contributing factor to this is the ideal duck cage density in Tegal, Pemalang and Brebes (0.4-0.6 $\mathrm{m}^{2} /$ bird) which is within a comfortable range for ducks in production period. Bai et al. (2020) reported that the house with a $5 \mathrm{bird} / \mathrm{m}^{2}$ stocking density is efficient for both maintenance and production. It also reflects low density in three regions of study. Furthermore, Li et al. (2018) demonstrated that the stocking density significantly affected livestock production and welfare. A much lower density would result in better product quality and management, but it also affects the economic lost because of the 
inefficient housing utilization. Wang et al. (2015) reported that an extremely high density could improve more production, but decrease performance, quality, and health of the livestock, as well as bad maintenance. Subagja et al. (2017) stated that a tight house would increase total carbon dioxide and reduce oxygen in the housing; as a result, the livestock growth is slowing down, egg production is low and mortality is increasing because the ducks become vulnerable to diseases.

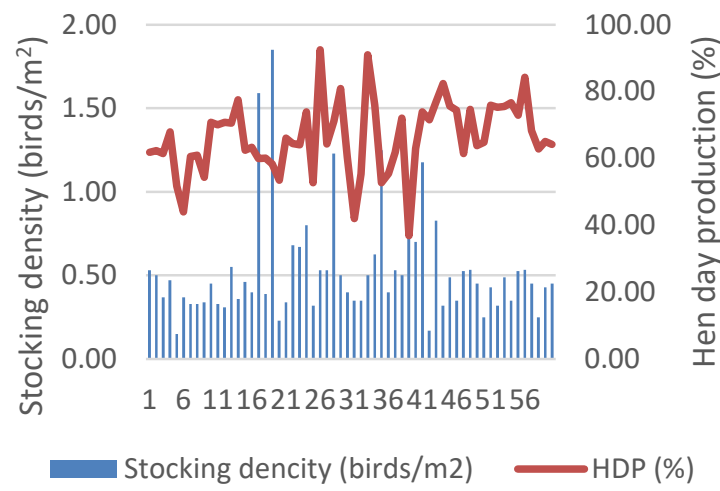

Figure 2. The Graph of stocking density and hen day production

The result of regression-correlation analysis demonstrates that housing humidity did not significantly affect egg production (Figure 3) where the average cage humidity in Tegal, Brebes and Pemalang is $65.36 \%, 60.57 \%$, and $62.61 \%$, respectively. The higher housing humidity in Tegal is potentially due to the close distance between the house and brackish water ponds, which makes the housing constantly wet. A study by Shoimah et al. (2019) reported a duck housing humidity by 50-70 \%. Meanwhile, Bai et al. (2020) argued that a high housing humidity would increase ammonia levels in the house which results in distress among livestock and reduced productivity.

The result of regression-correlation analysis shows that temperature affects egg production with the determination coefficient value $R^{2}=0.149$, correlation value of -0.386 and regression equation $\mathrm{Y}=121.78-2.125 \mathrm{X}$ (Figure 4).
It demonstrates that the higher the ambient temperature inside the housing, the lower the hen day egg production. Temperature is a factor affecting livestock productivity.

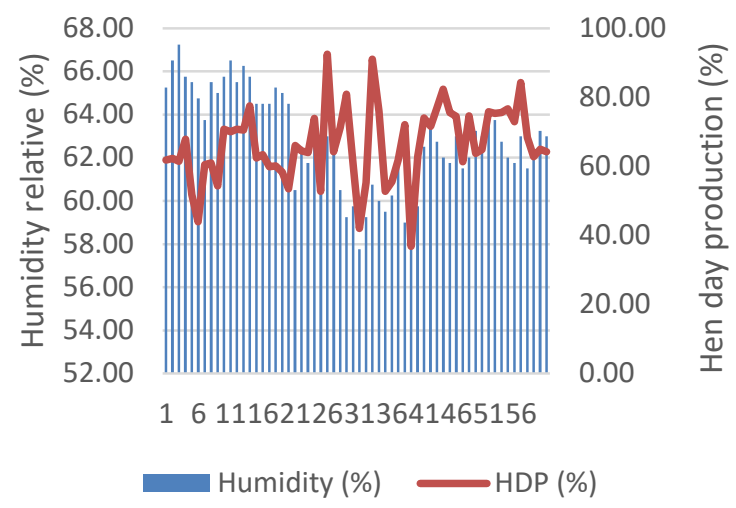

Figure 3. The graph of the average housing humidity and hen day production

The result shows that the ambient temperature in Tegal and Brebes is relatively higher than that in Pemalang $\left(27.5^{\circ} \mathrm{C}\right.$ and $27.4^{\circ} \mathrm{C}$ versus $23.4^{\circ} \mathrm{C}$ ); therefore, duck egg production is higher in Pemalang than the other regions. El Badry et al. (2009) suggests that the comfortable range of temperature for poultry is $18^{\circ} \mathrm{C}$ to $25^{\circ} \mathrm{C}$, while for native duck is $23^{\circ} \mathrm{C}$ to $25^{\circ} \mathrm{C}$. It demonstrates that the average temperature of cages in Tegal and Brebes has exceeded the comfort threshold. Widiawati et al. (2016) argued that ambient temperature above $25^{\circ} \mathrm{C}$ could increase energy demand in livestock; consequently, livestock production is not maximized. Toth et al. (2015) maintains that temperature is an important contributing factor in livestock production. A high temperature inside the cave would result in a low feed intake because the livestock would drink more to reduce heat stress, so they do not get sufficient nutrition intake and it disturbs productivity. Also, Ying et al. (2019) reported that high housing temperature would increase corticosterone level in the livestock's excreta, which then affects the increasing humidity and lowers livestock productivity due to heat stress. 


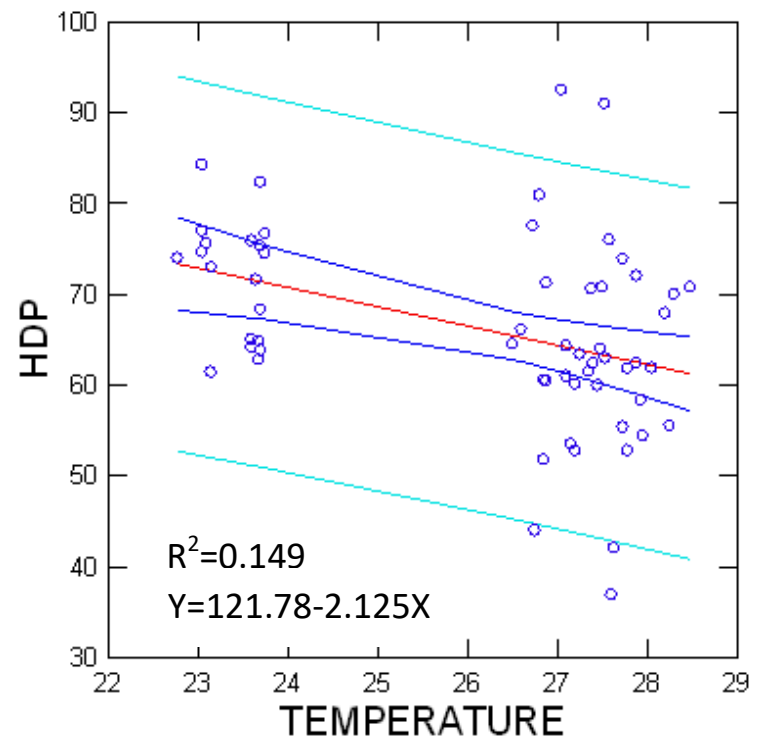

Figure 4. The effect of in-cage temperature on hen day production

The present study observed different livestock age across regions, but the ducks used in this research are 8-16 months old. The average livestock age in Pemalang, Brebes and Tegal were $12.65 \pm 1.8,11.75 \pm 2.24$ and 11.60 \pm 2.91 months, respectively. The result of regression-correlation analysis demonstrates that duck age affects egg production with the determination coefficient value $R^{2}=0.117$ with a regression value of $-0,342$ and regression equation $\mathrm{Y}=84.92-1.55 \mathrm{X}$ (Figure 5), which indicates that the older the ducks, the lower the egg production. Ariviani et al. (2019) stated that the initial laying age in ducks is between 20 to 43 weeks. Therefore, the ducks utilized in this study are within the range of peak production. Age is one of the determining factors of livestock productivity. Older ducks would experience lower productivity because the reproductive organs are no longer producing maximally. Similarly, under-age would affect egg quality (smaller egg size). Subagja et al. (2017) mentioned that the higher the livestock age, the lower the egg production. In duck life cycle, after the first production phase (12 months), ducks would undergo molting (1 month), and back to the second production phase with a lower production than the first phase. Subiharta et al. (2013) suggests that the initial laying age significantly affects the egg size and production time; the younger the laying ducks, the shorter the egg production phase.

The highest HDP value in Pemalang region is potentially due to older ducks in Pemalang than the other regions. Fouad (2016) stated that the factors affecting different HDP values are age, strain, research time, and feed offered. Meanwhile, Dahiya et al. (2016) reported that the contributing factors to livestock production are sexual maturity, livestock originality, livestock age, body weight, molting, as well as environmental factors, such as temperature, lighting, feed and feeding.

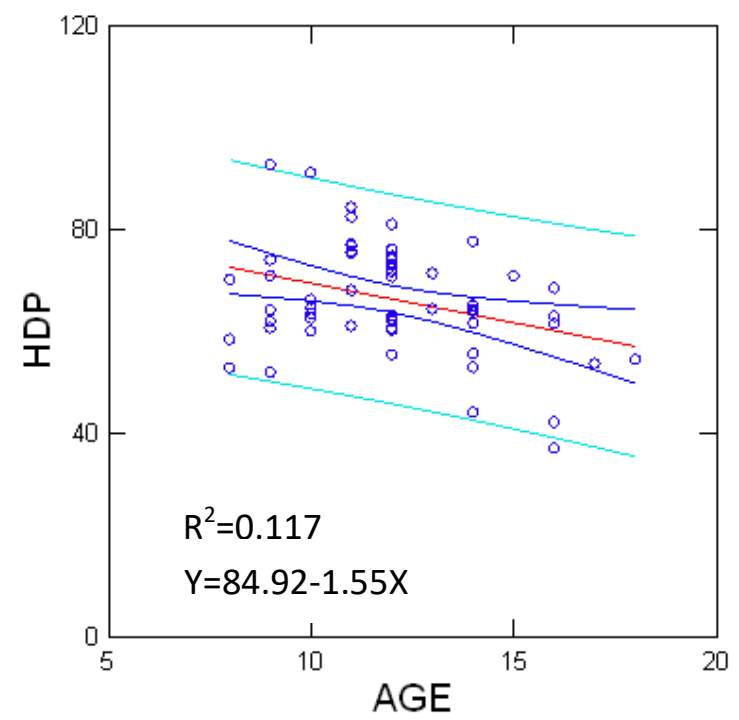

Figure 5 . The effect of duck age on egg production

\section{Conclusions}

Pemalang is the most suitable region for layer duck farming as opposed to Tegal and Brebes, as indicated from the highest hen day production. The three regions of duck farming in Central Java demonstrated relatively similar FCR values. The important environmental factors to egg production are the ambient temperature, while duck age is an internal factor affecting egg production.

\section{Acknowledgment}

This study was supported by the Director of Research and Development of the Directorate 
General of Higher Education, Ministry of Research, Technology and Higher Education of the Republic of Indonesia, with the Fundamental Research fund with contract number: 176/SP2H/LT/DRPM /2019.

\section{References}

Ariviani, S., G. Fauza and D. Ishartani. 2019. Peningkatan Kualitas and Umur Simpan Telur Asin di Industri Rumah Tangga Telur Asin Melalui Inovasi Proses Produksi. Prosiding PKM-CSR. 2(1): 355-360.

Badan Pusat Statistik. 2019. Central Java Dalam Angka 2019. Central Java.

Bai H., Q. Bao, Y. Zhang, Q. Song, B. Lin, L. Zhang, Z. Wang, Y. Jiang, Q. Xu, G. Chang and G. Chen. 2020. Effects of the Rearing Method and Stocking Density on Carcass Traits and Proximate Composition of Meat in Small-Sized Meat Ducks. Poultry Science. 99(4): 2011-2016.

Baruwa, O.I., A.A. Tijani and T. Alimi. 2018. Determinants of Technical Efficiency in Duck Production in Southwest Nigeria. Agricultura Topica Et Subtropica. 51(3): 113-120.

Basso, B., A. Bordas, F. Dubos, P. Morganx and C. Marie-Etancelin. 2012. Feed Eficiency in the Laying Duck: Appropriate Measurements and Genetic Parameters. Poultry Science. 91: 10651073.

Daghir, N.J. 2009. Nutritional Strategies to Reduce Heat Stress in Broilers and Broiler Breeders. Lohmann Information. 44: 6-15.

Dahiya, R., R.S. Berwal, S. Sihag, C.S. Patil and Lalit. 2016. The Effect of Dietary Supplementation of Salts of Organic Acid on Production Performance of Laying Hens. Veterinary World. 9(12): 14781484.

Direktorat Jenderal Peternakan dan Kesehatan Hewan. 2019. Statistik Peternakan dan Kesehatan Hewan 2019. Jakarta: Direktorat Jenderal Peternakan dan Kesehatan Hewan.

El-Badry, A.S.O., M.M. Hassanane, E.S. Ahmed and K.H. El-Kholy. 2009. Effect of Early-Age Acclimation on Some Physiological, Immunological Responses and Chromosomal Aberrations in Muscovy Ducks During Exposure to Heat Stress. Global J. Biotech. and Biochem. 4: 152-159.

Fouad, A.M., D. Ruan, Y.C. Lin, C.T. Zheng, H.X. Zhang, W. Chen, S. Wang, W.G. Xia and Y. Li. 2016. Effects of Dietary Methionine on Performance, Egg Quality and Glutathione Redox System in Egg-Laying Ducks. British Poultry Science. 57(6): 818-823.
Giri, S.C., S.K. Sahoo, S.K. Karna, S. Saran, K.V.H. Sastry and N. Kandi. 2014. Production Performance of Ducks under Extensive System of Management in Tribal Districts of Odisha. Indian Journal of Poultry Science. 49(1): 97-100.

Hastuti, D., R. Prabowo and A.A. Syihabudin. 2018. Tingkat Hen Day Production (HDP) and Break Event Point (BEP) Usaha Ayam Ras petelur (Gallus sp). Jurnal Agrifo. 3(2): 76-84.

Ismoyowati, D. Indrasanti and I.H. Sulistyawan. 2018. The Differences of Feed Quality and Egg Production Performance of Tegal and Magelang Ducks on Farming in Central Java. Bulletin of Animal Science, 42(3):197-202.

Ismoyowati and D. Purwantini. 2013. Produksi Dan Kualitas Telur Native duck Di Daerah Sentra Duck farming Egg Production and Quality of Local Ducks in Ducks Farming Center Area. Jurnal Pembangunan Pedesaan, 13(1): 1-10.

Ismoyowati and J. Sumarmono, 2019. Duck Production for Food Security. IOP Conf. Series: Earth and Environmental Science 372 (2019) 012070. doi:10.1088/1755-1315/372/1/012070.

Jones, T.A. and M.S. Dawkins. 2010. Environment and Management Factors Affecting Pekin Duck Production and Welfare on Commercial Farms in the UK. British Poultry Science. 51(1): 12-21.

Ketaren, P.P. and L.H. Prasetyo. 2002a. Pengaruh Pemberian Pakan Terbatas terhadap Duck egg production Silang Mojosari X Alabio (MA): 1. Masa Bertelur Fase Pertama Umur 20-43 Minggu. JITV. 7(1): 38-45.

Ketaren, P.P. and L.H. Prasetyo. 2002b. Pengaruh Pemberian Pakan Terbatas Terhadap Produktivitas Itik Silang Mojosari X Alabio (MA): 2. Masa Bertelur Fase Kedua Umur 44-67 Minggu. JITV. 7(2): 76-83.

Li, W., J. Yuan, Z. Ji, L. Wang, C. Sun and X. Yang. 2018. Correlation Search Between Growth Performance and Flock Activity in Automated Assessment of Pekin Duck Stocking Density. Computers and Electronics in Agriculture. 15(2): 26-31

Lin, H., H.C. Jiao, J. Buyse and E. Decuypere. 2006. Strategies for Preventing Heat Stress In Poultry. World's Poult. Sci. J. 62: $71-85$.

Manurung J.P., E. Suprijatna and V. Dwi. 2019. Pengaruh Pemberian Tepung Limbah Rumput Laut (Gracilaria sp.) dengan Aditif Multienzim dalam Pakan Terhadap Produksi Tegal duck. Jurnal Pengembangan Penyuluhan Peternakan. 16(29): 70-79.

Novi, M. 2019. Development Strategy of Duck Livestock In Semangga District Merauke Regency. Agricola. 9(2): 74-80.

Qurniawan, A., I.I. Arief and R. Afnan. 2016. Perormans Produksi Ayam Pedaging pada 
Lingkungan Pemeliharaan dengan Ketinggian yang Berbeda di Sulawesi Selatan. Jurnal Veteriner. 17(4): 622-633

Ratriyanto, A., B.F. Hidayat, N. Widyas and S. Prastowo. 2019. Kurva Egg production di Awal Masa Peneluran pada Puyuh yang diberi Ransum dengan Kandungan Protein Berbeda. Jurnal IImu Ternak Universitas Padjadjaran. 19(1): 28-35.

Rohimah, E. Dihansih and D. Kardaya. 2017. Production Performance of Male Local Ducks (Anas plathyrhinchos) Given Betel (Piper Betle Linn) Leave Extract Solution Included in Commercial Ration. Jurnal Peternakan Nusantara. 3(1): 17-22.

Samsudin A.A., N. Hendry and K.T. Khaing. 2016. Effects of Feeding Dietary Palm Kernel Cake on Eff Production and Egg Quality of Khaki Campbell Duck. Journal of World's Poultry Research. 6(1): 01-05.

Shoimah, D., I.H. Djunaidi and O. Sjofjan. 2019. Quality of Duck Eggs Maintained Using a Different Maintenance System in the Malang Raya Area. International Research Journal of Advance Engineering and Science. 4(4): 273-277.

Subagja, H., B. Prasetyo and H. Nurjanah. 2017. Faktor Produksi Usaha Ternak Itik Petelur Semi Intensif di Kabupaten Jember. Jurnal IImiah Inovasi. 17(2): 67-72

Subiharta, D.M. Yuwono and P. Sudrajad. 2013. Karakteristik Tegal duck (Anas plantyhynchos javanicus) Sebagai Itik Petelur Unggulan Lokal Central Java and Upaya Peningkatan Produksinya. Seminar Nasional: Menggagas Kebangkitan Komoditas Unggulan Lokal Pertanian and Kelautan. Universitas Trunojaya Madura. 300-310.

Sulistyawan, I.H., Ismoyowati and D. Indrasanti. 2018. Perbedaan Produksi Dan Kualitas Duck eggs Tegal Dan Magelang duck Di Tingkat Peternak. In Prosiding Seminar Teknologi Agribisnis Peternakan (Stap) Fakultas Peternakan Universitas Jenderal Soedirman. 6(pp): 205-209.

Susanti, A.E., A. Prabowo and S. Hanapi. 2016. Potensi Pakan di Rawa Lebak untuk Mendukung Budidaya Itik Pegagan Studi Kasus di Desa Kota Daro II. In Seminar Nasional Pertanian Peternakan Terpadu. 1(1).

Talukder, S., T. Islam, S. Sarker and M. Islam. 2010. Effect of Environment on Layer Performance. Journal Bangladesh Agriculture University. 8(2): 253-258.
Thiele, H.H. and B. Alletru. 2017. Feed Efficiency and Feeding Behaviour in Pekin Ducks. Lohman Information. 5(12): 30-35.

Toth, L.A., R.A. Trammell and M.I. Woods. 2015. Interactions Between Housing Density and Ambient Temperature in the Cage Environment Effect on Mouse Physiology and Behavior. Journal of the American Association for Laboratory Animal Science. 54(6): 708-717.

Wang, S., W. Chen, H.X. Zhang, D. Ruan and Y.C. Lin. 2015. Influence of Particle Size and Calcium Source on Production Performance, Egg Quality, and Bone Parameters in Laying Ducks. Poultry Science. 93:2560-2566.

Widianto, B., H.S. Prayogi and N. Nuryadi. 2015. Pengaruh Penambahan Tepung Buah Mengkudu (Morinda citrifolia L.) dalam Pakan Terhadap Penampilan Produksi Itik Hibrida. Jurnal IImuIlmu Peternakan. 25(2): 28-35.

Widiawati, Y., R. Sutrisna and Siswanto. 2016. Respon Fisiologis Itik Mojosari Jantan dengan Pemberian Ransum Berkadar Protein Kasar Berbeda. Jurnal Ilmiah Peternakan Terpadu. 4(3): 182-187.

Widiyaningrum, P., Lisdiana and N.R. Utami. 2016. Egg Production and Hatchability of Local Ducks Unnder Semi Intensive Vs Extensive Managements. Journal Indonesian Tropic Animal Agriculture. 41(2): 77-82.

Ying, Z., L.X. Mei, Z. Min-hong and F. Jing-hai. 2019. Effect of Relative Humidity at Either Acute or Chronic Moderate Temperature on Growth Performance and Droppings' Corticosterone Metabolites of Broilers. Journal of Integrative Agriculture. 18(1): 152-159

Zahan, M.N., M.K.N.B. Sufian, M.K. Rahman and M.S. Parvej. 2016. Socio Economic Status of Farmers and Production Performance of Khaki Campbell Ducks Reared Under Backyard Farming in Bangladesh. Wayamba Journal of Animal Science. 8: 1307-1311.

Zhang, Y.N., S. Wang, K.C. Li, D. Ruan, W. Chen, W.G. Xia, S.L. Wang, K.F.M. Abouelezz and C.T. Zheng. 2020. Estimation of Dietary Zinc Requirement for Laying Duck Breeders: Effects on Productive and Reproductive Performance, Egg Quality, Tibial Characteristics, Plasma Biochemical and Antioxidant Indices, and Zinc Deposition. Poultry Science. 99(1): 454-462. 